\section{Yield and Russeting of Greenhouse Tomato as Influenced by Leaf-to-fruit Ratio and Relative Humidity}

\author{
Dominique-André Demers ${ }^{1}$, Martine Dorais ${ }^{2}$, and \\ Athanasios P. Papadopoulos ${ }^{3}$ \\ Agriculture and Agri-Food Canada, Greenhouse and Processing Crops \\ Research Centre, 2585 County Road 20, Harrow, Ontario, Canada, N0R 1G0
}

Additional index words. Lycopersicon esculentum, cuticle cracks, fruit cracking, plant balance, leaf pruning, fruit thinning

\begin{abstract}
Three experiments were conducted in greenhouses 1) to determine the optimal leaf-to-fruit ratio for minimizing the incidence of russeting (miniature cuticle cracks on fruit) while optimizing fruit yield of greenhouse tomato (Lycopersicon esculentum Mill.) and 2) to investigate the effect of day/night relative humidity (RH) regimens on the development of russeting. Leaf-to-fruit ratio treatments $(0.5-2.0)$ were achieved by varying the number of fruit (two to six fruit) per cluster and the number of leaves (two to four leaves) between clusters. In one experiment, plants were also subjected to either high day/low night or low day/high night RH regimens (low RH, 60\% to 70\%; high RH, 85\% to $95 \%$ ). Results showed that russeting of greenhouse tomato was mostly influenced by the number of fruit per cluster (total fruit load), and very little by the number of leaves between clusters. In general, decreasing the number of fruit per cluster resulted in a progressive increase in the occurrence of russeting. Furthermore, as the number of fruit per cluster decreased, the percentage of fruit with no russeting and with little russeting decreased whereas the percentage of fruit with the more severe russeting increased (except for the summer). For beefsteak cultivars Trust and Rapsodie grown under southwestern Ontario conditions, the best pruning practices for minimizing russeting and optimizing yield was to prune clusters to three fruit in early spring and late fall, to four fruit during spring and fall, and to five fruit during the summer, with three leaves between clusters all year long. In the current study, no significant effect of day/night RH regimens on fruit russeting was observed. Of the cultivars used, $\mathrm{Rz} 74 / 56$ was less sensitive to russeting than 'Trust', whereas 'Rapsodie' was not different from the two other cultivars. However, all three cultivars had a very high incidence of russeting $(>65 \%$ of fruit affected), and none should be regarded as russeting resistant. Breeding programs and genetic investigations with the objective of developing greenhouse tomato cultivars resistant to russeting are needed.
\end{abstract}

Russeting, also known as cuticle cracking, has become a common problem in greenhouse tomato production and an important concern for commercial growers, and the causes of its development are extremely complex (Demers et al., 2001; Dorais et al. 2004). Bakker (1988) and Ehret et al. (1993) have suggested that the availability of assimilates to the fruit could be involved in the

Received for publication 24 July 2006. Accepted for publication 28 Nov. 2006.

Funded by Club Pro-Serre, DiCiocco Farms, and Agriculture and Agri-Food Canada through its Matching Investment Initiative program.

We gratefully thank J. Blackburn, C. Breault, M.H. Paré, and K. Vollans for their technical assistance. ${ }^{1}$ Current address: Biobest Canada Ltd., 2020 Fox Run Road, RR4, Leamington, Ontario, Canada, N8H 3 V7.

${ }^{2}$ Current address: Agriculture and Agri-Food Canada, Centre de Recherche et de Développement en Horticulture, 430 Bld Gouin, St-Jean sur le Richelieu, Quebec, Canada, J3B 3E6.

${ }^{3}$ To whom reprint requests should be addressed; e-mail papadopoulost@agr.gc.ca development of russeting in tomato. Assimilate availability to fruit can be modified by manipulating the number of fruit or leaves on plants. Commercial growers already manipulate the number of fruit and leaves on tomato plants to adjust the balance between vegetative and reproductive growth to maintain optimal plant vigor and high long-term productivity. Ehret et al. (1993) observed that increasing the leaf-to-fruit ratio (reduced number of fruit on plants) increased the incidence and severity of fruit russeting in tomato. Bakker (1988) and Ehret et al. (1993) observed that the incidence of russeting was more severe in the summer than in the fall and spring seasons, suggesting a possible implication of climatic conditions [light, temperature, relative humidity $(\mathrm{RH})]$. Huang and Snapp (2004) found that shoulder check, a disorder similar to russeting affecting field tomato, was associated with precipitation events alternating with hot, dry weather conditions during rapid fruit expansion. However, very few researchers have investigated the relationship between greenhouse tomato fruit russeting and climatic factors.
The main objective of this study was to determine the optimal leaf-to-fruit ratio for minimizing the incidence of russeting while optimizing yield of greenhouse tomato fruit. The second objective was to investigate the effect of day/night $\mathrm{RH}$ regimens on the development of fruit russeting in tomato.

\section{Materials and Methods}

Three experiments (summer, spring, and fall) were conducted in greenhouse compartments (cultivable area, $55.2 \mathrm{~m}^{2}$ each) covered with double-polyethylene film, at the Greenhouse and Processing Crops Research Center (Harrow, Ont., Canada; lat., $42^{\circ} 0^{\prime} \mathrm{N}$, long., $82^{\circ} 54^{\prime} \mathrm{W}$ ). Tomato plants (Lycopersicon esculentum Mill.) were grown on rockwool (plugs, cubes, and slabs for seedling, transplant, and cropping stages respectively) following standard commercial practices (Papadopoulos, 1991). Planting was done in a double-row pattern at a plant density of 2.6 plants $/ \mathrm{m}^{2}$. Minimum heating and venting temperatures were set at $17^{\circ} \mathrm{C}$ and $19{ }^{\circ} \mathrm{C}$ respectively. Relative humidity in the summer experiment was maintained between $70 \%$ and $90 \%$, with combined venting and heating to reduce $\mathrm{RH}$, and with high-pressure fogging to increase RH. A drip irrigation system was used to irrigate the plants daily with complete nutrient solution $(\mathrm{pH}, 5.0-5.5$; electrical conductivity, $1.6-3.5 \mathrm{dS} \cdot \mathrm{m}^{-1}$ ) (Papadopoulos, 1998). Fruit, harvested once or twice a week, was graded into no. 1 (extralarge, large, and small), commercial, no. 2, and unmarketable (e.g., blossom-end rot, cracked, cat faced) (Ontario Ministry of Agriculture, Food and Rural Affairs, 1987). Fruit russeting was visually evaluated using the following classification based on the extent of the fruit surface that was affected by russeting: grade 0 , no russeting; grade 1 , russeting between the calyx and the shoulder of the fruit only; grade 2, russeting from the calyx along the shoulder to half of the fruit; and grade 3 , russeting from the calyx to more than half of the fruit

Summer experiment. Tomato seed was sown on 23 Dec. 1998, and final planting in a greenhouse compartment occurred on 5 Feb. 1999. The experimental design was a split plot, with cultivar as the main factor and fruit thinning as the secondary factor, with four replicates. The cultivars used were 'Rapsodie' (Novartis), 'Rz 74/56' (Rijk Zwaan), and 'Trust' (DeRuiter). On 3 June, the following fruit-thinning treatments were applied to three plants within each replicate of "cultivar": three fruit/cluster, four fruit/cluster, and no fruit thinning (five fruit or more per cluster; referred to as five fruit/cluster in text and tables). No leaf pruning was performed as part of the treatments (three leaves between clusters). Fruit were harvested from 28 June until 12 Aug. Average daytime, nighttime, and 24-h average air temperatures and $\mathrm{RH}$ were $24.6{ }^{\circ} \mathrm{C}, 22.1{ }^{\circ} \mathrm{C}$, and $23.6^{\circ} \mathrm{C}$, and $80.6 \%, 88.3 \%$, and $83.6 \%$ respectively.

Fall experiment. Tomato seed, cv. Trust, was sown on 28 June 1999, and final planting 
in four greenhouse compartments occurred on 26 July 1999. The experimental design was a split plot with two day/night $\mathrm{RH}$ regimens as the main factor (replicated two times; i.e., two compartments/treatment) and leaf-to-fruit ratio as the secondary factor. Relative humidity regimens were low/high (low day RH, 60\% to 70\%; high night RH, $85 \%$ to $95 \%$ ) and high/low (high day $\mathrm{RH}$, $85 \%$ to $95 \%$; low night RH, $60 \%$ to $70 \%$ ). Relative humidity treatments were initiated on 3 Aug. Actual day and night RH of the two regimens, and outdoor conditions are shown in Fig. 1. The 24-h RH averages of the two treatments varied between $73 \%$ and $88 \%$, and generally differed by less than $5 \%$. Average daytime, nighttime, and 24-h average air temperatures were $23.4{ }^{\circ} \mathrm{C}, 20.2{ }^{\circ} \mathrm{C}$, and $22.1{ }^{\circ} \mathrm{C}$ in August, and $19.8{ }^{\circ} \mathrm{C}, 18.4{ }^{\circ} \mathrm{C}$, and $19.0^{\circ} \mathrm{C}$ in December respectively.

In each compartment, 18 plants were pruned to achieve each of the following six leaf-to-fruit ratios: 2 leaves between clusters : 4 fruit per cluster (0.5), 3 leaves between clusters : 4 fruit per cluster $(0.75), 3$ leaves between clusters : 3 fruit per cluster (1.0), 2 leaves between clusters : 2 fruit per cluster (1.0), 3 leaves between clusters : 2 fruit per cluster (1.5), and 4 leaves between clusters : 2 fruit per cluster (2.0). Clusters were pruned to the desired number of fruit after flowering had finished and fruit (pea size) were visible. At the same time, leaf pruning (if necessary) was performed immediately below the cluster that was just pruned. Tomato plants generally develop three leaves between clusters; therefore, no leaf pruning was necessary for treatments with three leaves. For treatments with two leaves, the first two leaves immediately below the cluster were kept and the third leaf was removed. For the treatment with four leaves, a side shoot was allowed to develop at the node of the first leaf below the cluster; the side shoot was then topped after it had developed one leaf. Fruit was harvested from 23 Sept. until 13 Dec. On 13 Dec., plants were destructively sampled for growth measurements (leaf: area, fresh weight, dry weight; stem: thickness, length, fresh weight, and dry weight).

Spring experiment. Tomato seed was sown on 10 Dec. 1999, and final planting in four greenhouse compartments was on 20 Jan. 2000. Average daytime, nighttime, and 24-h average air temperatures were $21.4{ }^{\circ} \mathrm{C}, 19.5$ ${ }^{\circ} \mathrm{C}$, and $20.3{ }^{\circ} \mathrm{C}$ in January, and $23.3^{\circ} \mathrm{C}, 20.7$ ${ }^{\circ} \mathrm{C}$, and $22.3{ }^{\circ} \mathrm{C}$ in June respectively. For $\mathrm{RH}$, daytime, nighttime, and 24-h averages were $77 \%, 64 \%$, and $69 \%$ in January, and $82 \%$, $85 \%$, and $83 \%$ in June respectively.

The experimental design was a split plot with leaf-to-fruit ratio as the main factor and cultivar as the secondary factor, with four replicates. Cultivars used were 'Rapsodie' and 'Trust'. Within each compartment and cultivar, nine tomato plants were pruned to achieve each of the following six leaf-to-fruit ratios: 2 leaves between clusters : 4 fruit per cluster $(0.5), 3$ leaves between clusters : 4 fruit per cluster $(0.75), 4$ leaves between clusters : 4 fruit per cluster (1.0), 3 leaves between clusters : 3 fruit per cluster (1.0), 2 leaves between clusters : 2 fruit per cluster

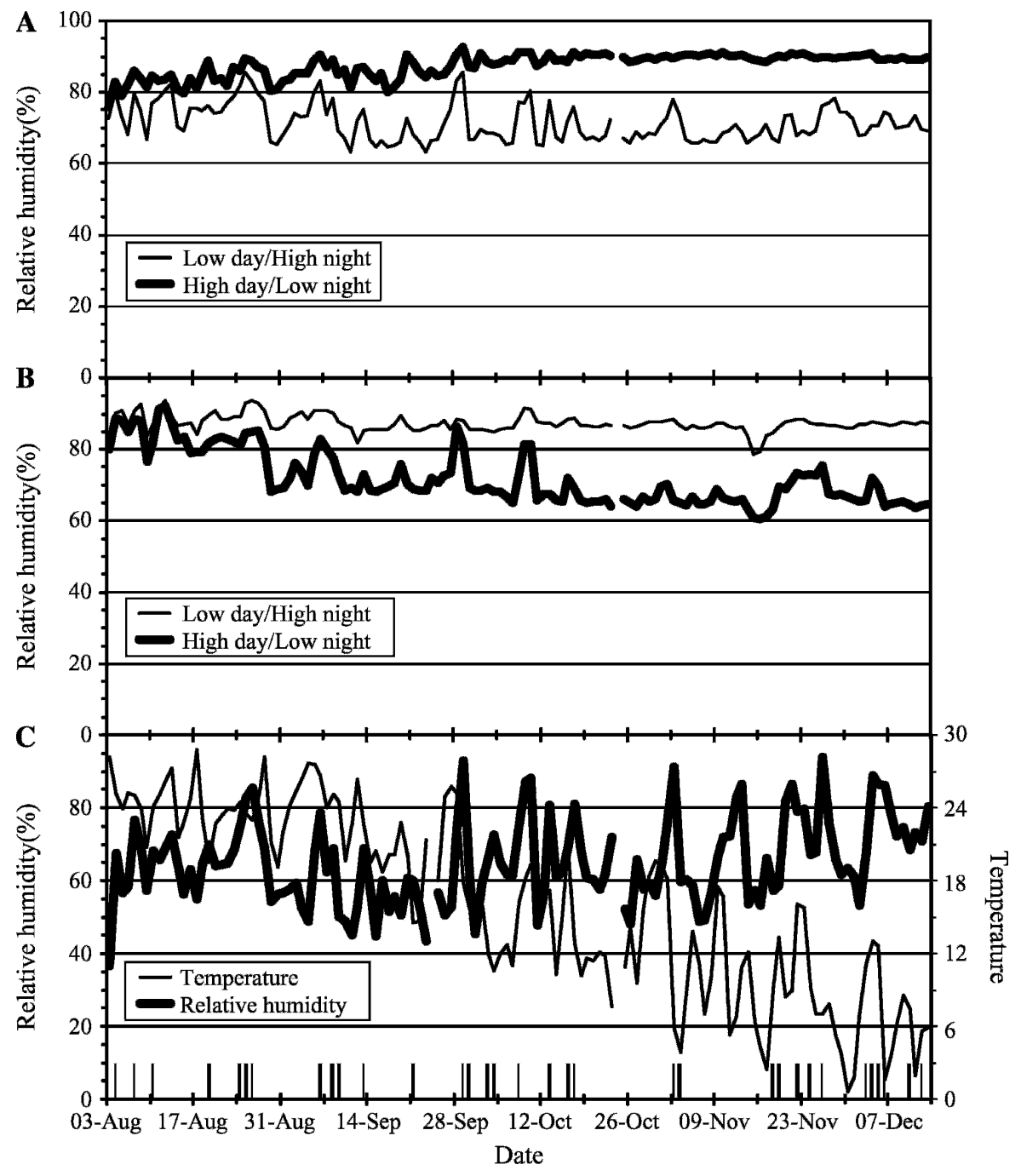

Fig. 1. (A-C) Relative humidity $(\mathrm{RH})$ in the two $\mathrm{RH}$ regimen treatments during daytime $(\mathbf{A})$ and nighttime (B), and outdoor conditions (C). Vertical lines on the $\mathrm{x}$-axis indicate days with precipitation over the course of the fall experiment.

(1.0), and 3 leaves between clusters : 2 fruit per cluster (1.5). Because results from the summer experiment indicated that 5 fruit/ cluster was best for decreasing russeting during summertime, two treatments were modified on 8 May to include a treatment with 5 fruit/cluster for the summer period and also a treatment with 6 fruit/cluster to test whether a number of fruit per cluster larger than five may further decrease russeting. The treatments 2 leaves between clusters : 4 fruit per cluster $(0.5)$ and 3 leaves between clusters : 2 fruit per cluster (1.5) were changed to 3 leaves between clusters : 6 fruit per cluster $(0.5)$ and 3 leaves between clusters : 5 fruit per cluster (0.6) respectively. Fruit and leaf pruning was performed as described for the fall experiment. Fruit was harvested from 28 Mar. until 26 June.

\section{Results}

Influence of leaf-to-fruit ratio on yield and growth. Decreasing the number of fruit per cluster from five to four and three in the summer experiment, and from four to three and two in the fall and spring experiments caused a progressive decrease in the number of fruit harvested and an increase in the average fruit size (Table 1). The increased fruit size as the number of fruit per cluster was decreased corresponded to an increase in the percentage of extralarge fruit harvested and a decrease in the percentage of large fruit. In the fall and spring experiments, the increased fruit size in treatments with 2 fruit/ cluster did not compensate for the decreased number of fruit harvested, and resulted in a lower yield (on a weight basis), compared with treatments with 3 or 4 fruit/cluster. In the spring experiment, yield characteristics among the treatments 3 leaves between clusters : 4 fruit per cluster, 4 leaves between clusters : 4 fruit per cluster, 3 leaves between clusters : 3 fruit per cluster, 2 leaves between clusters : 2 fruit per cluster, and 2 leaves between clusters : 4 fruit per cluster ( 3 leaves between clusters : 6 fruit per cluster after 8 May) remained until 26 June (data not shown). Furthermore, by the end of the experiment (last 2 weeks), yield characteristics (number and weight of harvested fruit, mean fruit size, 
Table 1. Influence of fruit thinning, leaf-to-fruit ratio, day/night relative humidity, and cultivar on the yield of greenhouse tomato fruit.

\begin{tabular}{|c|c|c|c|c|c|c|}
\hline \multirow[b]{2}{*}{ Expts and treatments } & \multicolumn{6}{|c|}{ Marketable fruit } \\
\hline & No./plant & $\mathrm{kg} /$ plant & $\%$ & Size $(\mathrm{g})$ & Extra-large $(\%)^{z}$ & Large $(\%)^{z}$ \\
\hline \multicolumn{7}{|l|}{ Summer } \\
\hline \multicolumn{7}{|l|}{ Fruit/cluster } \\
\hline 3 & $17.8 b^{y}$ & 2.81 & 94 & $159 \mathrm{a}$ & $25 \mathrm{a}$ & $67 \mathrm{~b}$ \\
\hline 4 & $21.3 \mathrm{a}$ & 3.06 & 95 & $144 \mathrm{~b}$ & $19 \mathrm{ab}$ & $74 \mathrm{ab}$ \\
\hline 5 & $22.9 \mathrm{a}$ & 3.09 & 95 & $135 \mathrm{~b}$ & $13 \mathrm{~b}$ & $77 \mathrm{a}$ \\
\hline \multicolumn{7}{|l|}{ Cultivars } \\
\hline Rapsodie & 20.9 & 3.11 & 95 & 151 & $25 \mathrm{a}$ & $67 \mathrm{~b}$ \\
\hline Rz 74/56 & 19.6 & 2.85 & 94 & 145 & $19 \mathrm{ab}$ & $71 \mathrm{~b}$ \\
\hline Trust & 21.5 & 3.02 & 95 & 141 & $12 \mathrm{~b}$ & $79 \mathrm{a}$ \\
\hline \multicolumn{7}{|l|}{ Fall } \\
\hline \multicolumn{7}{|l|}{ Leaf-to-fruit ratio } \\
\hline $2 \mathrm{~L}: 4 \mathrm{~F}(0.5)$ & $15.8 \mathrm{~b}$ & $2.56 \mathrm{~b}$ & 83 & $162 \mathrm{c}$ & $24 \mathrm{c}$ & $61 \mathrm{a}$ \\
\hline $3 \mathrm{~L}: 4 \mathrm{~F}(0.75)$ & $18.9 \mathrm{a}$ & $3.07 \mathrm{a}$ & 89 & $162 \mathrm{c}$ & $26 \mathrm{c}$ & $61 \mathrm{a}$ \\
\hline $3 \mathrm{~L}: 3 \mathrm{~F}(1.0)$ & $15.6 \mathrm{~b}$ & $2.96 \mathrm{a}$ & 87 & $190 \mathrm{~b}$ & $40 \mathrm{~b}$ & $49 \mathrm{~b}$ \\
\hline $2 \mathrm{~L}: 2 \mathrm{~F}(1.0)$ & $10.4 \mathrm{c}$ & $2.24 \mathrm{c}$ & 84 & $215 \mathrm{a}$ & $62 \mathrm{a}$ & $28 \mathrm{c}$ \\
\hline $3 \mathrm{~L}: 2 \mathrm{~F}(1.5)$ & $11.1 \mathrm{c}$ & $2.41 \mathrm{bc}$ & 86 & $217 \mathrm{a}$ & $60 \mathrm{a}$ & $29 \mathrm{c}$ \\
\hline $4 \mathrm{~L}: 2 \mathrm{~F}(2.0)$ & $11.9 \mathrm{c}$ & $2.52 \mathrm{bc}$ & 89 & $211 \mathrm{a}$ & $56 \mathrm{a}$ & $32 \mathrm{c}$ \\
\hline \multicolumn{7}{|l|}{$\mathrm{RH}$ regimens } \\
\hline Low/high & 13.9 & 2.63 & 86 & 190 & 45 & 42 \\
\hline High/low & 14.1 & 2.62 & 86 & 186 & 42 & 47 \\
\hline \multicolumn{7}{|l|}{ Spring } \\
\hline \multicolumn{7}{|l|}{ Leaf-to-fruit ratio } \\
\hline $2 \mathrm{~L}: 4 \mathrm{~F}(0.5)$ & $15.0 \mathrm{a}$ & $2.67 \mathrm{~b}$ & 90 & $176 \mathrm{c}$ & $48 \mathrm{~b}$ & $37 \mathrm{a}$ \\
\hline $3 \mathrm{~L}: 4 \mathrm{~F}(0.75)$ & $16.8 \mathrm{a}$ & $3.03 \mathrm{a}$ & 93 & $179 \mathrm{c}$ & $49 \mathrm{~b}$ & $33 \mathrm{a}$ \\
\hline $4 \mathrm{~L}: 4 \mathrm{~F}(1.0)$ & $15.8 \mathrm{a}$ & $2.92 \mathrm{a}$ & 89 & $185 \mathrm{c}$ & $54 \mathrm{~b}$ & $31 \mathrm{a}$ \\
\hline $3 \mathrm{~L}: 3 \mathrm{~F}(1.0)$ & $12.4 \mathrm{~b}$ & $2.71 \mathrm{ab}$ & 90 & $218 \mathrm{~b}$ & $66 \mathrm{ab}$ & $17 \mathrm{~b}$ \\
\hline $2 \mathrm{~L}: 2 \mathrm{~F}(1.0)$ & $8.5 \mathrm{c}$ & $2.32 \mathrm{c}$ & 90 & $273 \mathrm{a}$ & $74 \mathrm{a}$ & $6 \mathrm{c}$ \\
\hline $3 \mathrm{~L}: 2 \mathrm{~F}(1.5)$ & $8.8 \mathrm{c}$ & $2.40 \mathrm{bc}$ & 92 & $273 \mathrm{a}$ & $72 \mathrm{a}$ & $8 \mathrm{c}$ \\
\hline \multicolumn{7}{|l|}{ Cultivars } \\
\hline Rapsodie & 13.6 & $3.00 \mathrm{a}$ & $94 \mathrm{a}$ & $232 \mathrm{a}$ & $65 \mathrm{a}$ & $18 \mathrm{~b}$ \\
\hline Trust & 12.2 & $2.36 \mathrm{~b}$ & $87 \mathrm{~b}$ & $203 \mathrm{~b}$ & $56 \mathrm{~b}$ & $26 \mathrm{c}$ \\
\hline
\end{tabular}

${ }^{2}$ Percentage values calculated over marketable fruit weight.

'In each column, within each experiment and treatment, values followed by different letters are significantly different at $P<0.05$ (Duncan's multiple range test). In all three experiments, there was no significant interaction between pruning treatments, cultivars, and relative humidity $(\mathrm{RH})$ treatments.

etc.) of the modified treatment 3 leaves between clusters : 5 fruit per cluster became similar to those of treatments 3 leaves between clusters : 4 fruit per cluster and 4 leaves between clusters : 4 fruit per cluster (data not shown).

In the fall experiment, growth of tomato plants was affected mostly by the number of fruit per cluster, but also by the number of leaves between clusters. In general, area, weight (fresh and dry) and specific leaf weight (SLW) of individual leaves as well as thickness and weight (fresh and dry) of the stem progressively increased as the number of fruit per cluster decreased (data not shown). For treatments with 2 fruit/ cluster, area, weight, and SLW of individual leaves increased as the number of leaves decreased.

Influence of leaf-to-fruit ratio on russeting. In general, decreasing the number of fruit per cluster resulted in a progressive increase in the occurrence of russeting (total percentage of fruit with russeting; Table 2). Furthermore, as the number of fruit per cluster decreased, the percentage of fruit with no russeting and with little russeting (grade 1) decreased whereas the percentage of fruit with the more severe russeting (grades 2 and 3) increased (except in the summer experiment), which resulted in an increase in the mean russeting grade (representing the severity of russeting).
Relative humidity. The day/night RH regimens had no significant effect on the yield (number or weight of fruit; percentage of marketable, extralarge, large, or small fruit) or russeting (occurrence and severity) of tomato (Tables 1 and 2). Furthermore, the yield and russeting responses of the tomato plants to the leaf-to-fruit ratio treatments was similar under the two day/night $\mathrm{RH}$ regimens (i.e., the interaction "leaf-to-fruit ratio $\times \mathrm{RH}$ regime" was not significant), which in the fall and spring was significantly correlated with fruit size (Fig. 2).

Cultivars. In the summer experiment, there was no difference in yield (number or weight of fruit harvested), percentage of marketable fruit, or mean fruit weight among the three cultivars (Table 1). The cultivar Trust produced significantly less extralarge fruit, but more large fruit than 'Rapsodie'. In the spring experiment, 'Rapsodie' produced more (number and weight) and larger fruit (mean size, percentage of extralarge fruit) than 'Trust' (Table 1).

In the summer experiment, the least susceptible cultivar to russeting (lowest percentage of fruit with russeting) was ' $R Z$ 74/56', but was only significantly different from 'Trust' (Table 2). In both summer and spring experiments, there was no difference in the russeting of tomato fruit of the cultivars 'Rapsodie' and 'Trust'. In the two experiments, the yield and russeting responses of the cultivars to the pruning treatments were similar (i.e., the interaction "fruit pruning $\times$ cultivar" was not significant).

\section{Discussion}

Our results support those of Ehret et al. (1993), who also found that increasing the leaf-to-fruit ratio resulted in increased incidence and severity of fruit russeting in greenhouse tomato. Under our Southwestern Ontario conditions, the optimal leaf-to-fruit ratio for minimizing russeting while maximizing yield of greenhouse tomato was 0.75 (3 leaves between clusters : 4 fruit per cluster). However, russeting of tomato fruit was dependent mostly on the number of fruit per cluster, and very little on the number of leaves between clusters or the actual value of the leaf-to-fruit ratio. This is clearly demonstrated by the fact that russeting in the three treatments with 2 fruit/cluster did not increase as the leaf number increased from two to three and four (fall experiment), and also by the fact that russeting in the three treatments with a leaf-to-fruit ratio of 1.0 increased as the number of fruit per cluster (and leaves between clusters) decreased from four to three and two (spring experiment).

Bakker (1988) and Ehret et al. (1993) suggested that increased assimilate supply to fruit may cause increased russeting of tomato fruit. Therefore, in the treatments with 4 fruit/ cluster, increasing the number of leaves between clusters from two to three and four (spring experiment) should have caused a progressive increase in russeting, which we did not observe. However, pruning to two leaves between clusters exposes the fruit to more sunlight. Direct fruit exposure to light increased fruit temperature (Cockshull et al., 1992), which can result in increased gas pressure inside the fruit and can cause the fruit to expand in volume, thus stretching the skin of the fruit (Corey and Tan, 1990). Increased cuticular cracking resulting from increased fruit temperature resulting from exposure of the fruit to direct light has been shown in greenhouse sweet pepper (Capsicum annuum L.) (Moreshet et al., 1999), but not in tomato. It has also been shown in apples, but not in tomato, that direct fruit exposure to solar radiation can modify the polymerization of the cuticle waxes into an amorphous matrix, which is more susceptible to cracking (Faust and Shear, 1972). Therefore, the decreased russeting that should have been observed in the 2 leaves between clusters : 4 fruit per cluster treatment may have been negated by an increased russeting resulting from increased fruit exposure to light. The increased shading of the fruit in the treatment with four leaves between clusters, which prevents increased fruit temperature, may have also negated any anticipated increase in russeting as a result of increased assimilate supply to fruit.

In treatments with 2 fruit/cluster (fall experiment), the progressive increase in the size, weight, and SLW of individual leaves as the number of leaves decreased from four 
Table 2. Influence of fruit thinning, leaf-to-fruit ratio, day/night relative humidity, and cultivar on the russeting of greenhouse tomato fruit.

\begin{tabular}{|c|c|c|c|c|c|c|}
\hline \multirow[b]{2}{*}{ Expts and treatments } & \multicolumn{5}{|c|}{ Percentage of fruit ${ }^{z}$} & \multirow[b]{2}{*}{ Mean grade ${ }^{y}$} \\
\hline & $\begin{array}{l}\text { No russeting } \\
\text { (grade 0) }\end{array}$ & $\begin{array}{l}\text { With russeting } \\
\text { (grades } 1,2,3 \text { ) }\end{array}$ & Grade 1 & Grade 2 & Grade 3 & \\
\hline \multicolumn{7}{|l|}{ Summer } \\
\hline \multicolumn{7}{|l|}{ Fruit/cluster } \\
\hline 3 & $21 b^{x}$ & $79 \mathrm{a}$ & $44 \mathrm{a}$ & 24 & 10 & 1.56 \\
\hline 4 & $24 \mathrm{~b}$ & $75 \mathrm{a}$ & $42 \mathrm{a}$ & 23 & 8 & 1.51 \\
\hline 5 & $35 \mathrm{a}$ & $65 \mathrm{~b}$ & $33 \mathrm{~b}$ & 22 & 10 & 1.62 \\
\hline \multicolumn{7}{|l|}{ Cultivars } \\
\hline Rapsodie & $26 \mathrm{ab}$ & $74 \mathrm{ab}$ & 37 & 24 & $10 \mathrm{a}$ & 1.62 \\
\hline Rz 74/56 & $34 \mathrm{a}$ & $66 \mathrm{~b}$ & 38 & 21 & $7 \mathrm{~b}$ & 1.48 \\
\hline Trust & $19 \mathrm{~b}$ & $80 \mathrm{a}$ & 44 & 25 & $11 \mathrm{a}$ & 1.58 \\
\hline \multicolumn{7}{|l|}{ Fall } \\
\hline \multicolumn{7}{|l|}{ Leaf-to-fruit ratio } \\
\hline $2 \mathrm{~L}: 4 \mathrm{~F}(0.5)$ & $49 \mathrm{a}$ & $51 \mathrm{c}$ & $26 \mathrm{a}$ & $11 \mathrm{~b}$ & $13 \mathrm{~b}$ & $1.74 \mathrm{~b}$ \\
\hline $3 \mathrm{~L}: 4 \mathrm{~F}(0.75)$ & $52 \mathrm{a}$ & $48 \mathrm{c}$ & $22 \mathrm{ab}$ & $14 \mathrm{~b}$ & $13 \mathrm{~b}$ & $1.82 \mathrm{~b}$ \\
\hline $3 \mathrm{~L}: 3 \mathrm{~F}(1.0)$ & $36 \mathrm{~b}$ & $64 \mathrm{~b}$ & $26 \mathrm{a}$ & $16 \mathrm{~b}$ & $22 \mathrm{~b}$ & $1.94 \mathrm{~b}$ \\
\hline $2 \mathrm{~L}: 2 \mathrm{~F}(1.0)$ & $18 \mathrm{c}$ & $82 \mathrm{a}$ & $17 \mathrm{bc}$ & $26 \mathrm{a}$ & $38 \mathrm{a}$ & $2.27 \mathrm{a}$ \\
\hline $3 \mathrm{~L}: 2 \mathrm{~F}(1.5)$ & $12 \mathrm{c}$ & $88 \mathrm{a}$ & $14 \mathrm{c}$ & $27 \mathrm{a}$ & $47 \mathrm{a}$ & $2.37 \mathrm{a}$ \\
\hline $4 \mathrm{~L}: 2 \mathrm{~F}(2.0)$ & $14 \mathrm{c}$ & $85 \mathrm{a}$ & $17 \mathrm{cb}$ & $28 \mathrm{a}$ & $41 \mathrm{a}$ & $2.27 \mathrm{a}$ \\
\hline \multicolumn{7}{|l|}{ RH regimens } \\
\hline Low/high & 33 & 66 & 21 & 20 & 25 & 2.06 \\
\hline High/low & 30 & 70 & 20 & 20 & 31 & 2.15 \\
\hline \multicolumn{7}{|l|}{ Spring } \\
\hline \multicolumn{7}{|l|}{ Leaf-to-fruit ratio } \\
\hline 2L : 4F (0.5) & $85 \mathrm{a}$ & $15 \mathrm{c}$ & 5 & 3 & $7 \mathrm{~b}$ & $1.98 \mathrm{~b}$ \\
\hline $3 \mathrm{~L}: 4 \mathrm{~F}(0.75)$ & $80 \mathrm{a}$ & $20 \mathrm{c}$ & 9 & 3 & $8 \mathrm{~b}$ & $1.91 \mathrm{~b}$ \\
\hline $4 \mathrm{~L}: 4 \mathrm{~F}(1.0)$ & $82 \mathrm{a}$ & $18 \mathrm{c}$ & 8 & 4 & $5 \mathrm{~b}$ & $1.71 \mathrm{~b}$ \\
\hline $3 \mathrm{~L}: 3 \mathrm{~F}(1.0)$ & $70 \mathrm{~b}$ & $30 \mathrm{c}$ & 7 & 5 & $17 \mathrm{ab}$ & $2.31 \mathrm{a}$ \\
\hline $2 \mathrm{~L}: 2 \mathrm{~F}(1.0)$ & $57 \mathrm{c}$ & $42 \mathrm{a}$ & 8 & 7 & $26 \mathrm{a}$ & $2.38 \mathrm{a}$ \\
\hline $3 \mathrm{~L}: 2 \mathrm{~F}(1.5)$ & $47 \mathrm{c}$ & $53 \mathrm{a}$ & 12 & 10 & $30 \mathrm{a}$ & $2.33 \mathrm{a}$ \\
\hline \multicolumn{7}{|l|}{ Cultivars } \\
\hline Rapsodie & 67 & 33 & 10 & 6 & 18 & 2.12 \\
\hline Trust & 74 & 26 & 7 & 5 & 14 & 2.09 \\
\hline
\end{tabular}

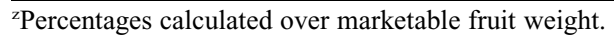

${ }^{y}$ Mean grade $=[($ weight of grade 1 fruits $)+($ weight of grade 2 fruits $\times 2)+($ weight of grade 3 fruits $\times 3)]$ (weight of all fruits with russeting). Mean grade value (an index of russeting severity) could vary from 1 (least severe) to 3 (most severe).

${ }^{x}$ In each column, within each experiment and treatment, values followed by different letters are significantly different at $P<0.05$ (Duncan's multiple range test). In all three experiments, there was no significant interaction between pruning treatments, cultivars, and relative humidity (RH) treatments.

to three and two suggests that the leaves were photosynthetically more productive. These larger and heavier leaves may have individually provided more assimilates to the fruit, and thus compensated for the decreased number of leaves, which may explain why fruit russeting of the three treatments with 2 fruit/cluster was not different.

In treatments with the same number of leaves, fruit russeting increased as the number of fruit per cluster decreased (more assimilate for the remaining fruits), which supports the hypothesis that the assimilate supply plays a role in the development of tomato fruit russeting. Decreasing the number of fruit per cluster also resulted in an associated increase in the average fruit size. Ehret et al. (1993) also observed that increasing the leaf-to-fruit ratio increased fruit size. Thus, it is possible that the increased assimilate supply to fruit resulting from an increased leaf-to-fruit ratio caused the increased russeting by producing larger fruit (Fig. 2). The skin of large fruit is submitted to a greater stress than the skin of small fruit, and therefore should be more likely to crack, according to the theoretical model of Considine and Brown (1981). However, hypothesis that a high day/low night $\mathrm{RH}$ regime and an associated wide variation in the water supply to the fruit promote russeting was further supported by the findings of Huang and Snapp (2004), who reported that shoulder check (a similar disorder in field tomatoes) was promoted by precipitation events alternating with hot and dry weather periods. However, in our experiment, we found no difference in fruit russeting (occurrence and severity) of tomato plants grown under high day/low night and low day/high night RH regimens. Schilstra-van Veelen and Bakker (1985) also observed no difference in fruit russeting of tomato plants grown under low day/high night and high day/ low night RH regimens (high RH, 87\%; low RH, 78\%). On the other hand, Simard (2001) noted that greenhouse tomato fruit russeting was positively correlated with the 24-h RH average (last $14 \mathrm{~d}$ before harvest), but not with the day/night RH differential. Because the difference between the 24-h $\mathrm{RH}$ averages of the two $\mathrm{RH}$ regimens in our experiment was small $(<5 \%)$, this may explain why we did not observe an influence of the RH regimens on tomato fruit russeting.

The cultivars Rapsodie and Trust, which are frequently used by commercial growers, showed no significant difference in their susceptibility to russeting in two experiments. Even though ' $\mathrm{Rz} 74 / 56$ ' was less russeting sensitive than 'Trust', russeting incidence in all three cultivars was very high, and none of these cultivars can be considered resistant to russeting. To our knowledge, no truly russeting-resistant cultivars of greenhouse tomato are available. Because greenhouse tomato fruit russeting has become a concern only recently, few studies have been done on the genetics of russeting resistance in tomato. Emmons and Scott (1998a, b) showed that it is possible to breed for russeting resistance in tomato. In their studies on russeting-resistant and -sensitive cultivars of tomato (and their crosses), these researchers found that cultivars with thicker epicarp were more resistant to russeting, but that fruit characteristics such as fruit shape and pedicel type (jointed vs. jointless) were not related to russeting resistance.

In summary, to minimize russeting while optimizing yield over the course of a 1-year production cycle, we suggest that clusters be pruned to five fruit during the summer (June until August), and to four fruit during spring (March until May) and fall (September until December), with the possibility to prune to three fruit in early spring and late fall. Leaves do not need to be pruned, other than those at the bottom of the plants, as they enter senescence. In the current study, day/ night $\mathrm{RH}$ regimens did not affect tomato fruit russeting. However, the influence of $\mathrm{RH}$ on russeting of tomato fruit deserves further investigation. Future studies should include additional factors that influence plant and fruit water status. To develop greenhouse tomato cultivars resistant to russeting, fruit characteristics that confer increased resistance 

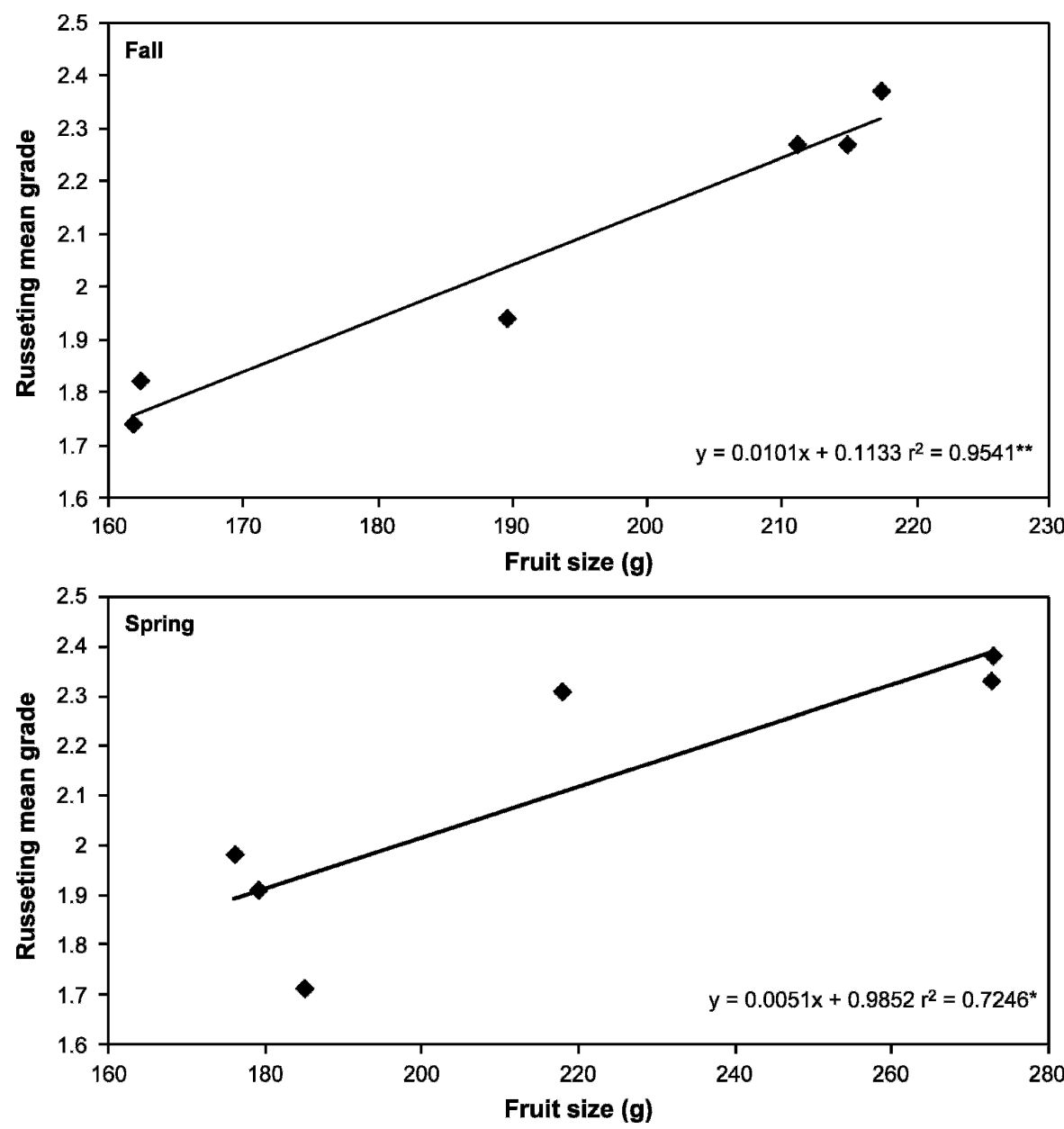

Fig. 2. Relationship between tomato fruit size and the mean russeting grade, an index of russeting severity ranging from 1 (least severe) to 3 (most severe), in the fall and spring. Lines represent linear regression analysis of the means. ${ }^{*}, * *$ Significance of the correlation coefficient at $P=0.05$ and 0.01 levels respectively. Data represent the mean of 36 plants.

to russeting, and the genes that control those characteristics, need to be further investigated.

\section{Literature Cited}

Aloni, B., L. Karni, I. Rylski, Y. Cohen, Y. Lee, M. Fuchs, S. Moreshet, and C. Yao. 1998. Cuticular cracking in bell pepper fruit: I. Effects of night temperature and humidity. J. Hort. Sci. Biotechnol. 73:743-749.
Corey, K.A. and Z.Y. Tan. 1990. Induction of changes in internal gas pressure of bulky plant organs by temperature gradients. J. Amer. Soc. Hort. Sci. 115:308-312.

Demers, D.-A., A.P. Papadopoulos, M. Dorais, M.-H. Paré, K. Vollans, and J. Blackburn. 2001. Influence of mineral nutrition $(\mathrm{Ca}, \mathrm{N}, \mathrm{P}, \mathrm{Cl})$ on yield and russeting of tomato fruits, p. 6-8. Greenhouse Vegetable Res. Team Ann. Rpt. Agr. Agri-Food Canada, Greenhouse Processing Crops Res. Ctr., Harrow, Ont., Canada.

Dorais, M., D.-A. Demers, A.P. Papadopoulos, and W. Van Ierepen. 2004. Greenhouse tomato fruit cuticle cracking. Hort. Rev. (Amer. Soc. Hort. Sci.) 30:163-184.

Ehret, D.L., T. Helmer, and J.W. Hall. 1993 Cuticle cracking in tomato fruit. J. Hort. Sci. 68:195-201

Emmons, C.L.W. and J.W. Scott. 1998a. Diallel analysis of resistance of cuticle cracking in tomato. J. Amer. Soc. Hort. Sci. 123:67-72.

Emmons, C.L.W. and J.W. Scott. 1998b. Ultrastructural and anatomical factors associated with resistance to cuticle cracking in tomato (Lycopersicon esculentum Mill.). Int. J. Plant Sci. 159:14-22.

Faust, M. and C.B. Shear. 1972. Russeting of apples, an interpretive review. HortScience 7:233-235.

Huang, J.-C. and S.S. Snapp. 2004. The effect of boron, calcium, and surface moisture on shoulder check, a quality defect in fresh-marke tomato. J. Amer. Soc. Hort. Sci. 129:599-607.

Moreshet, S., C. Yao, B. Aloni, L. Karni, M. Fuchs, and C. Stanghellini. 1999. Environment factors affecting the cracking of greenhouse-grown bell pepper fruit. J. Hort. Sci. Biotechnol. 74:6-12.

Ontario Ministry of Agriculture, Food and Rural Affairs. 1987. Greenhouse tomatoes grading and packing manual. Ontario Ministry of Agriculture, Food and Rural Affairs, Food Inspection Branch, Guelph, Ont., Canada.

Papadopoulos, A.P. 1991. Growing greenhouse tomatoes in soil and soilless media. Agr. Agri-Food Canada publ. no. 1865/E. Ottawa, Ont., Canada.

Papadopoulos, A.P. 1998. Seasonal fertigation schedules for greenhouse tomatoes: Concepts and delivery systems. Acta Hort. 458:123-140.

Schilstra-van Veelen, I.M. and J.C. Bakker. 1985. Cracking of tomato fruits. Annual report. Glasshouse Crops Research Expt. Sta., Naaldwijk, the Netherlands.

Simard, K. 2001. L'influence de la conduite des cultures sur l'incidence et la sévérité du microfendillement de la cuticule de la tomate de serre produite au Québec. Mémoire de maîtrise, Faculté des Études Supérieures, Université Laval, Ste-Foy, Qc, Canada. 